\title{
5-A-SIDE SOCCER: PREVALENCE OF SPORTS INJURIES IN BRAZILIAN TEAM PLAYERS
}

\author{
FUTEBOL DE 5: PREVALÊNCIA DE LESÕES ESPORTIVAS EM JOGADORES DA SELEÇÃOBRASILEIRA \\ FÚTBOL 5: PREVALENCIA DE LESIONES DEPORTIVAS EN JUGADORES DE LA SELECCIÓN BRASILEÑA
}

ORIGINAL ARTICLE ARTIGo ORIGINAL Artículo Original

\begin{abstract}
Thálita Gonçalves Santos' (iD (Physical Education Professional) Jalusa Andreia Storch² (iD (Physical Therapist and Physical Education Professional)

Marília Passos Magno e Silva ${ }^{3}$ (D) (Physical Therapist)

Luis Felipe Castelli Correia de Campos ${ }^{4}$ (D)

(Physical Education Professional) José Júlio Gavião de Almeida ${ }^{5}$ (ID (Physical Education Professional) Edison Duarte ${ }^{5}$ (ID

(Physical Therapist)
\end{abstract}

1. Faculdade de Americana, Americana, SP, Brazil.

2. Universidade Federal de Catalão, Department of Physical Education, Catalão, GO, Brazil.

3. Universidade Federal do Pará, Instituto de Ciências da Saúde, School of Physical Therapy and Occupational Therapy, Belém, PA, Brazil.

4. Universidad del Bío Bío,

Department of Educational Sciences, School of Physical Education Pedagogy, Chillán, Chile. 5. Universidade Estadual de Campinas, School of Physical Education, Department of Adapted Phyical Activity Studies, Campinas, SP, Brazil.

\section{Correspondence}

Thálita Gonçalves Santos Av. Érico Veríssimo, 701 - Cidade Universitária Zeferino Vaz, Campinas, São Paulo, Brazil. CEP 13.083-851

\begin{abstract}
Introduction: 5-a-side soccer is a sports modality exclusively for athletes with vision impairment (VI) classified as blind - B1 (Blind 1) by the visual classification process. Type of impairment and high-performance training are factors that contribute to the development of sports injuries. Objective: The purpose of this study was to characterize the prevalence of sports-related injuries in visually disabled athletes of the Brazilian 5-a-side soccer team. Methods: The method was defined as a descriptive, longitudinal, epidemiological study. The sample was composed of ten male athletes, members of the Brazilian 5-a-side soccer team, including two athletes without $\mathrm{Vl}$ and eight athletes with the B1 visual classification, who participated in competitions in 2014. The questionnaire for the data collection was based on the Sport Injuries Protocol for Paralympic Sports (PLEEP), expressing quantitative data analyzed by descriptive statistics. Results: The results showed that, in 2014, five athletes with VI had seven sports injuries, with a prevalence of $62.5 \%$, clinical incidence of 0.87 injuries per athlete per year, and 1.4 injuries per injured athlete. The main sports injuries were muscle strain (28.6\%), groin pull (athletic pubalgia) (28.6\%), and shin splints (periostitis) (28.6\%). All sports injuries occurred in the lower limbs, affecting legs (71.4\%) and hips (28.6\%). Overload was the most frequent mechanism (57\%), reported after the technical kick movement and linked to the muscle imbalance between dominant and supporting lower limbs, in addition to the postural misalignment typical of people with visual impairments. Conclusion: In summary, the Brazilian 5-a-side soccer athletes presented a pattern of overload injuries resulting from the repetition of the technical kick movement, occurring predominantly in sports competitions. Epidemiological data can contribute to the development of strategies to prevent injuries in this sport. Level of evidence II, Progressive prognostic study.
\end{abstract}

Keywords: Athletic injuries; Soccer; Para-athletes.

\section{RESUMO}

Introdução: O Futebol de 5 é uma modalidade exclusiva para atletas com deficiência visual (DV) inseridos no processo de classificação visual como cegos - B1 (Blind 1). A deficiência e o treinamento de alto desempenho são fatores que contribuem para o desenvolvimento de lesões esportivas. Objetivos: O objetivo do estudo foi caracterizar a prevalência das lesões esportivas em atletas com DV da Seleção Brasileira de Futebol de 5. Métodos: O método foi definido pelo estudo epidemiológico descritivo longitudinal. A amostra foi composta por dez atletas do sexo masculino da Seleção Brasileira de Futebol de 5, sendo dois atletas sem DV e oito atletas com DV com classificação visual B1, convocados para competições no ano de 2014. O questionário para a coleta de dados foi baseado no Protocolo de Lesão Esportiva no Esporte Paralímpico (PLEEP), expressando dados quantitativos analisados pela estatística descritiva. Resultados: Os resultados demonstraram que no ano de 2014, cinco atletas com DV tiveram sete lesões com prevalência de 62,5\%, incidência clínica de 0,87 lesões/atleta/ano e 1,4 lesões por atleta lesionado. As principais lesões esportivas foram estiramento muscular (28,6\%), pubalgia (28,6\%) e periostite (28,6\%). Todas as lesões ocorreram nos membros inferiores, afetando pernas $(71,4 \%)$ e quadril $(28,6 \%)$. A sobrecarga foi o mecanismo mais frequente (57\%), sendo relatada após a ação técnica do chute e vinculada ao desequilíbrio muscular entre membros inferiores dominante e de apoio, além dos desajustes posturais típicos da deficiência visual. Conclusão: Frente ao exposto, atletas do Futebol de 5 apresentaram um padrão de lesões por sobrecarga decorrentes das repetições da ação técnica do chute, ocorrendo predominantemente em competições esportivas. Os dados epidemiológicos podem contribuir para o desenvolvimento de estratégias na prevenção de lesões nesta modalidade esportiva. Nível de evidência II, Estudo prognóstico retrospectivo.

Descritores: Traumatismos em atletas; Futebol; Paratletas.

\section{RESUMEN}

Introducción: El Fútbol 5 es una modalidad exclusiva para deportistas con discapacidad visual (DV) insertadosen el proceso de clasificación visual como ciegos - B1 (Ciegos 1). La discapacidad y el entrenamiento de alto rendimiento son algunos de los factores que contribuyen al desarrollo de lesiones. Objetivo: el objetivo del estudio fue caracterizar la prevalencia de lesiones deportivas en deportistas con DV de la Selección Brasileña de Fútbol 5. Métodos: el método 
se definió mediante un estudio epidemiológico descriptivo longitudinal. La muestra estuvo conformada por diez atletas masculinos de la Selección Brasileña de Fútbol 5, dos atletas sin DV y ocho con DV, invitados a competencias en 2014. El cuestionario para la recolección de datos se basó en el Protocolo de Lesiones Deportivas en el Deporte Paraolímpico (PLEEP), expresando datos cuantitativos analizados por estadística descriptiva. Resultados: Ios resultados mostraron que en 2014, cinco deportistas con DV tuvieron sietelesiones, con prevalencia del 62.5\%, incidencia de 0.87 lesiones por atleta por año y 1.4 lesiones por atleta lesionado. Las principales lesiones deportivas fueron estiramiento muscular (28,6\%), pubalgia (28,6\%) y periostitis (28,6\%). Todas las lesiones ocurrieron en miembros inferiores afectando piernas $(71,4 \%)$ y caderas (28,6\%). La sobrecarga fue el mecanismo más frecuente (57\%), siendo reportado después de la acción técnica de patada y vinculado al desequilibrio muscular entre las extremidades inferiores dominantes y de apoyo, además de los desajustes posturales típicos de la discapacidad visual. Conclusión: los deportistas de Fútbol mostraron un patrón de lesiones por sobrecarga resultante de la repetición de la acción técnica de patada ocurriendo predominantemente en competencias deportivas. Los datos epidemiológicos pueden contribuir al desarrollo de estrategias para prevenir lesiones en este deporte. Este estudio tiene nivel de evidencia II, considerado un estudio

\section{pronóstico retrospectivo.}

Descriptores: Traumatismos en atletas; Fútbol; Paratletas.

\section{INTRODUCTION}

5-a-side soccer refers to the sports modality practiced exclusively by athletes with visual impairment (VI) classified as B $1^{1}$ according to the standards of the International Blind Sport Federation (IBSA), through analysis of the visual field and visual acuity by evaluating the Minimum Angle of Resolution of the E Algorithm/log MAR. ${ }^{2}$ Thus, class B1 has visually acuity below logMAR $2.60,{ }^{2}$ indicating athletes who may have light perception but are unable to recognize shapes, regardless of distance or direction. ${ }^{3}$

Blind athletes tend to have space-time, perception, awareness, and body control limitations that result in muscle imbalances. ${ }^{4,5}$ According to the sensory and motor stimulation received, gait speed may be slow and step length may be short, causing shifting position and running in the sport to occur with a broad base and semi-flexion of the hips and knees. This results in a lowering of the athlete's center of gravity in relation to the ground in order to increase balance, provide stability, and readjust postural control, especially of the lumbo-pelvic-hip complex. These particularities can influence the biomechanics of the lower limbs, resulting in misalignment and structural overload on bones and joints, as well as on muscles, ligaments, and tendons. ${ }^{6}$

High demand for volume and intensity in 5-a-side soccer training, associated with repetitiveness of sports movements and/or cumulative overloads generated in the lower limbs of the athletes, result in stress on the pelvis promoted by the medial rotation of the hip due to a lack of flexibility and the strength of three muscle groups: glutei, abductors, and abdominals. ${ }^{7,8}$ These muscle injuries are associated with insufficiency of basic sports fundamentals, such as shooting, change of direction, sudden stops, and unipedal support. ${ }^{9}$

Muscle imbalance between the dominant and non-dominant lower limbs can compromise the efficient use of both limbs when performing sports moves. ${ }^{10}$ However, in elite athletes these imbalances can be corrected through monitoring by the multidisciplinary team with the application of adequate and precise interventions.

The factors mentioned above contribute to the development of sports injuries (SI) in this sport. 5-a side soccer was the sport with the highest injury rate in the 2012 Paralympic Games in London, resulting in injuries in $31.4 \%$ of a sample of 70 athletes, with an incidence rate of 22.4 per 1000 athletes/day, 54\% of which were acute injuries, 23\% were chronic injuries, and $23 \%$ due to overload. ${ }^{11}$. The main cause was disrespect for the rules of the game. ${ }^{11}$
In an epidemiological study, the injury incidence rate in 5-a-side soccer was 22.4 (14.1 to 33.8) and the percentage of injured athletes was $31.4 \%$, the highest percentage in relation to the other sports analyzed. ${ }^{12}$ The commonly injured body segments were the lower limbs, mainly from mechanical overload. ${ }^{12}$ Twelve acute traumatic injuries occurred among the 56 players, with an incidence of 21.4 and an incidence rate of 15.3 (confidence interval of 7.6-23). Acute and overload injuries both occurred five times with an incidence of 8.9 and incidence rate of 6.4 (confidence interval of 2.1-14.8). ${ }^{12}$ As regards the moment at which the injuries were felt, six (10.71\%) occurred during training and eight (14.28\%) in competitions, while the others were divided between moments before the game and during practice of another sport. ${ }^{12}$

The details of the injuries are important for their classification and to obtain better results from preventive work. Given the above, the objective of this study was to characterize the prevalence of sports injuries in the visually impaired athletes playing on the 2014 Brazilian 5-a-side soccer team.

\section{METHODS}

This is a descriptive, longitudinal, epidemiological study of preparatory, pre-competition, and competition periods. ${ }^{13}$

\section{Participants}

A convenience sample of ten male athletes from the Brazilian 5-a-side soccer team selected for the 2014 competitions participated in the study. Of the ten athletes on the team, eight were visually impaired and two, who acted as goalies, were not. The study results refer to the eight visually impaired athletes. The athletes participating in the survey won titles, such as the Paralympic Games tri-championship, four-time World Champion, and two-time Pan-American Champion. ${ }^{14}$

\section{Data collection tool}

We used the Sports Injuries Protocol for Paralympic Sports (PLEEP) in questionnaire form as the collection tool. ${ }^{15}$ The information included: a) characterization of the athlete; b) modality; c) training; d) sports injuries, including the diagnosis, cause and symptoms of the sports injury.

The questionnaire was administered by a member of the technical team, and the information was compared against the team database. The Brazilian Confederation of Sports for the Visually Impaired (CBDV) granted access to the athletes and the database for study purposes. The UNICAMP Ethics Committee protocol opinion number is 795.615 and the CAAE number is 30959414.9.0000.5404. 


\section{Statistical analysis}

The data were analyzed by means of descriptive statistics, using the mean and standard deviation in order to describe the distribution of the types and anatomical locations of the injuries found in the athletes. ${ }^{13}$

\section{Definition of terms}

Sports injury (SI): tissue injury or other disturbance of normal physical function due to participation in sports, resulting from repetitive or rapid transfer of kinetic energy. ${ }^{16}$

Prevalence: number of athletes who have an injury divided by the total number of athletes at risk at a given time. ${ }^{15,16}$

Incidence: number of new cases of injuries in the population during a defined time period, divided by the population exposed to the risk. ${ }^{17,18}$ Incidence is indicated as a rate, with the term "incidence rate" as a synonym. ${ }^{16}$

Mechanism: classified as acutely occurring "traumatic injuries" resulting from a single impact or macro trauma, classified as either contact or non-contact traumas. "Overload injuries" originate from microtraumas from repetition, repetitive physical loads, and/or inadequate recovery of the musculoskeletal system, of sudden gradual onset. ${ }^{19}$

Degree of severity: measured by the type and duration of treatment, time away, time lost at work, permanent damage, or treatment costs. 20,21 The degree of severity of the injuries was defined by the athlete's period of absence from training or competition, ${ }^{22}$ classified as light ( 0 days absent), minimal (1-3 days), mild (4-7 days), moderate (8 to 28 days of absence), severe (more than 28 days away), and disabling (injury that prevents the athlete from returning to practicing sports). ${ }^{22}$

Location: is related to the hemibody, position, segment, body region, and body structure. ${ }^{15}$ In this study, we used the affected body structure to define location.

\section{RESULTS}

Of the eight visually impaired athletes, five (62.5\%) had congenital impairment and three (37.5\%) had acquired impairment. The mean age was $27 \pm 5.4$ years, the mean body weight was $76 \pm 6.1 \mathrm{Kg}$, and the mean height was $1.71 \pm 0.06 \mathrm{~m}$. They had a mean time of 12 years playing sports, with an average of 16 years for non-injured athletes and 10 years for injured athletes.

Table 1 below presents the epidemiological data of the injuries identified in the analyzed group. It is noteworthy that the number of injuries divided by the number of injured athletes equals 1.4, meaning that some athletes had more than one injury during the study period.

Diagnoses of the injuries that affected the 5 -a-side soccer athletes can be observed in Figure 1.

All injuries occurred in the lower limbs, affecting legs (71.4\%) and hips (28.6\%), with the description of the structures presented in Figure 2. Regarding the time away from the sport of the injured athletes, four (57.1\%) injuries caused absences of more than 21 days, one (14.3\%) an absence of 48 hours, and two (28.6\%) injuries caused changes in training

Table 1. Epidemiological injury data.

\begin{tabular}{c|c|c}
\hline & $\begin{array}{c}\text { Athletes } \\
\text { with VI }\end{array}$ & $\begin{array}{c}\text { Athletes } \\
\text { without VI }\end{array}$ \\
\hline Athlete & 8 & 2 \\
\hline Injured athletes & 5 & 0 \\
\hline Number of injuries & 7 & 0 \\
\hline Injuries reported during training & 3 & 0 \\
\hline Injuries reported during competition & 4 & 0 \\
\hline Prevalence & $62.50 \%$ & 0 \\
\hline Incidence (injuries/athlete/year) & 0.87 & 0 \\
\hline
\end{tabular}

Key: Vl=Visual impairment.

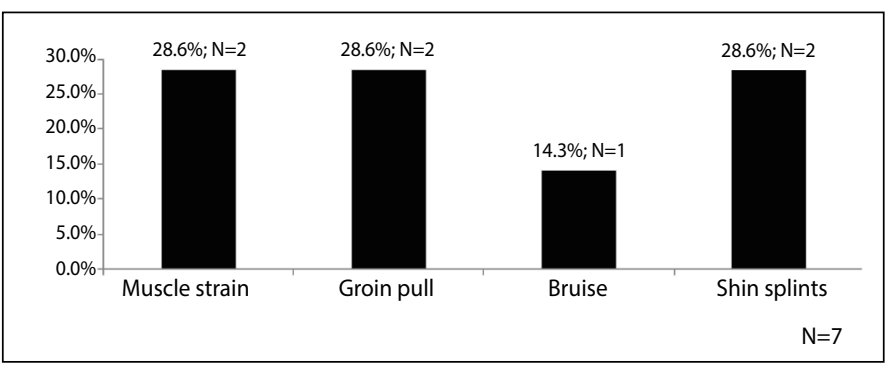

Figure 1. Diagnosis of the participants' sports injuries.

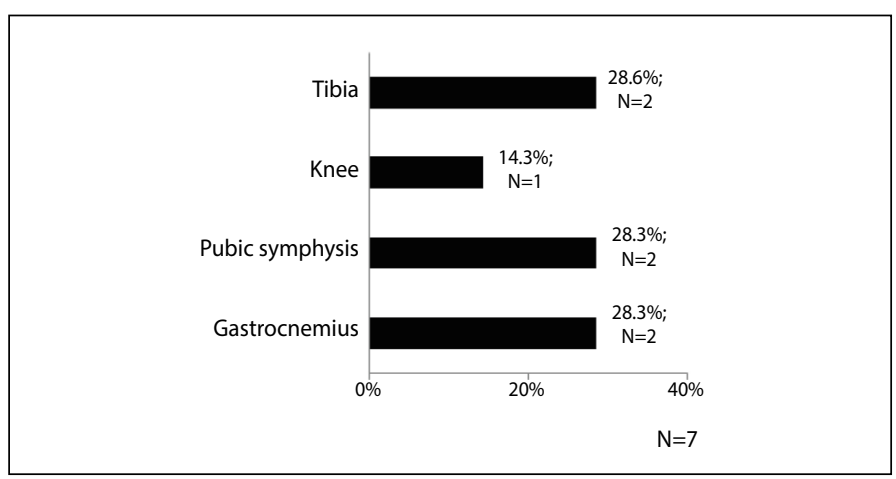

Figure 2. Body structures affected by sports injuries.

with a decrease in load and increase in supervision, without requiring any period of absence.

As for the injury mechanisms, four (57\%) of the seven injuries presented were overload injuries and three (43\%) were due to trauma mechanisms. The sports move most associated with sports injury was kicking.

\section{DISCUSSION}

The physical ability of athletes has improved drastically in recent years, such that they are able to run faster, performing technical fundamentals and precise actions. ${ }^{23}$

A study conducted with 13 athletes during five competitions (between 2004 and 2008) reported an average of 3.18 injuries/athlete, a prevalence of $84.6 \%$, a clinical incidence of 2.7 injuries/athlete, and a total of 35 sports injuries. ${ }^{8}$ Muscle strain, groin pull, bruises and shin splints were diagnosed in our study, as shown in Figure 1, contrary to what was shown in previous studies in the literature where injuries such as bruises (31.4\%) were the most often reported, followed by tendinopathies (8.6\%) and sprains (25.7\%). ${ }^{8}$

There were two cases of groin pull in this study (Figure 1), classified as a tendinopathy, resulting from inflammation of the muscles that are inserted or originate in the pubis and caused by an imbalance in muscle strength or elasticity, ${ }^{24}$ as well as to the repetitiveness of sports moves like kicking. The injury mechanism in the pubis consists of the absorption of descending and ascending forces applied to this structure and the sacroiliac joint, subjecting them to conditions of mechanical stress. ${ }^{7,24}$ In this study, the groin pull was considered a moderately severe injury ${ }^{22}$ because the associated period of absence is longer than 21 days.

From a biomechanical point of view, for the fundamental kick action that influences the development of a groin pull, the athlete's approach to the ball with bells is accomplished by means of a displacement with short steps in a side-to-side direction. ${ }^{25}$ The execution of the kick requires action predominantly of the dominant lower limb, which starts with knee flexion, hip extension, and pelvic anteversion, followed by the movement of propelling the ball forward, with knee extension, hip flexion, and pelvic retroversion. Thus, in the dominant lower limb there is a high angular velocity of contraction of the agonist muscles (quadriceps, femoral, iliopsoas), in addition to the force of stretching and deceleration applied by the antagonist muscles such as the hamstring muscles. ${ }^{25} \mathrm{On}$ 
the other hand, the non-dominant contralateral lower limb performs muscle contraction of the plant foot on the ground, which requires good control and central stabilization of the core muscles (abdominal muscles, spinal muscles, glutes, pelvic floor, and diaphragm) ${ }^{25}$

The factors of imbalance between the dominant and non-dominant limbs in habitual gait and in displacements during the soccer game tend to overload the anterior body region. Aimed at protection, an anterior inclination of the trunk and, consequently, the lowering of the center of gravity occur. This movement influences the execution of the kick, discharging greater force on the plant foot. For passes and kicks, the players adopt specific adaptations of the movements of the upper limbs and flexion of the trunk, which, together with the overload, leads to postural disarray. ${ }^{23}$

Shin splints (periostitis of the tibialis anterior) in 5-a-side soccer, characterized as an overload injury, were considered a less serious injury and without the need for an absence of the athlete. Shin splints can result from intermittent alternation between low, medium, and high intensity runs, causing inflammation of the periosteum both from an overload mechanism and direct trauma. ${ }^{9}$ Lesions due to tendinopathies, such as the groin pulls and shin splints described in this study, appear in 8.6\% of the cases in another study found in the literature. ${ }^{8}$

Particularly in the ankle and the foot, external forces are absorbed by passive structures (tendons, ligaments, fascia, and bone) and by periarticular contractile tissues (muscles), which also are determined by the type of plantar arch of the athlete (normal, concave, or flat). However, injuries linked to this biomechanical behavior are not evident in this sport.

The muscle strains observed in this study were classified as moderate injuries, due to the absence being longer than 21 days, and grade II injuries, in terms of progressive severity. ${ }^{9,22}$ Strain can affect any soft tissue, such as muscle, fascia, tendons, and biarticular muscles. It occurs when the tissue is exposed to a violent contraction or excessive stretching force, leading to damage to muscle fibers. ${ }^{9}$

Regarding injury mechanisms, the least reported traumatic injury was bruising, resulting from sudden compression force trauma causing rupture of subcutaneous structures or muscle tissue, culminating in edema. ${ }^{9}$ The severity of the bruise is related to the force of the impact of the trauma. ${ }^{9}$ In this study, the bruises were mild, with no period of absence, different from previous studies where bruises (31.4\%) and knee injuries (28.6\%) occurred with greater frequency. ${ }^{8}$ Acute injuries appeared in the literature with $54 \%$ of involvement, ${ }^{11}$ an incidence of de $21.4 \%$, and an incidence rate of $15.3 \% .^{12}$

Sensorimotor disadvantages can influence the development of injuries in the lower limbs. In 5-a-side soccer, there is a need for effective responses to constant sound stimuli (ball with bells, shouting "voy" when attacking the opponent, goalie, caller, and referee) present in high input, there being, thus, a demand for quick motor response from players to execute sudden stops, changes of direction, passes, and dribbles. ${ }^{26}$
The panorama of the prevalence of injuries in 5-a-side soccer was presented in a different way during periods of training and competition. Injuries by overload mechanisms had a higher prevalence, corroborating two epidemiological studies. ${ }^{11,12}$ However, our results were different from the findings presented in previous studies (Figure 3), in which $80 \%$ of the injuries were caused by a sports injury mechanism and $20 \%$ by an overload mechanism. ${ }^{8,12,27}$ This fact is supported by the 5 -a-side soccer requirements in relation to the high levels of aerobic and anaerobic conditioning, the need for rapid changes in direction, abrupt stops, technical effort, rapid recovery, ${ }^{28}$ competitiveness, and aggressiveness involved in the games.

We emphasize that attention should be paid to cycles of periodization that present more intense physical and technical demands, since imbalances in load distribution, volume, intensity, and the recovery period can cause muscle and joint overload predisposing the athlete to the development of injuries, especially during periods of competition. Aerobic fitness also influences the performance and competitive level of the players, since the greater the cardiovascular capacity of the athletes, the better their competitive performance. ${ }^{28}$

To control risk factors, the use of protective equipment, combined with work related to spatial orientation and auditory perception, can collaborate with the trauma reduction process. In order to manage injuries and risk factors, it is essential that health care be handled by an interprofessional team.

Future study perspectives could include comparative analyses of sports injuries as a result of the rules, control models for the distribution of training load and training components, such as flexibility and strength. Additionally, we reinforce the use of technologies involving sensors and artificial intelligence that can assist athletes to detect the location and movement of the objects around them more accurately. ${ }^{29}$

\section{CONCLUSION}

5-a-side soccer athletes predominantly presented injuries from overload mechanisms, resulting from the kicking sports move. Affecting the lower limbs, they are diagnosed as muscle strain, shin splints, and groin pulls. These injuries interfered with the activity of the athletes, since more than half of them triggered a leave of absence of more than 21 days.

\section{ACKNOWLEDGMENTS}

The Brazilian Confederation of Sports for the Visually Impaired [Confederação Brasileira de Desporto para Deficientes Visuais (CBDV)].

The National Council for Scientific and Technical Development [Conselho Nacional de Desenvolvimento Científico e Tecnológico (CNPQ)].

All authors declare no potential conflict of interest related to this article

AUTHORS' CONTRIBUTIONS: Each author made significant individual contributions to this manuscript. ETGS and JAS were the main contributors to the writing of the manuscript, also performing data acquisition, analysis or interpretation for the work, contributing substantially to the intellectual content of the work in its concept and design ": MPMS actively participated in the discussion of the results, the writing and critical review of its intellectual content, as well as participating in the review and approval of the final version of the manuscript.. LFCCC performed the data acquisition for the work and the critical review of the intellectual content; JJGA performed the critical review of its intellectual content; ED contributed to the intellectual concept of the work and also approved the final version of the manuscript for publication.

\section{REFERENCES}

1. Mello MT, Winclker CW. Esporte Paralímpico. São Paulo: Editora Atheneu; 2012.

2. Salvia LDe. IBSA Classification Manual for Classifiers.[Internet]. 2017 [acesso em 2021 mar 5]. Disponível em: http://www.ibsasport.org/documents/files/144-1-IBSA-Classification-Manual-classifiers.pdf

3. Ravensbergen HJCR, Mann DL, Kamper SJ. Expert consensus statement to guide the evidence-based classification of Paralympic athletes with vision impairment: A Delphi study. Br J Sports Med. 2016;50:386-91.

4. Armstrong LE, VanHeest JL. The unknown mechanism of the overtraining syndrome: clues from depression and psychoneuroimmunology. Sport Med. 2002;32(3):185-209.

5. Almeida JG, Winckler C. Deficiência Visual: Conceitos e Características. In: Souza RP, Campos LFCC, Gorla J. Futebol de 5: Fundamentos e Diretrizes. São Paulo: Editora Atheneu; 2014. p. 10-20.

6. Nakamura T. Quantitative analysis of gait in the visually impaired. Disabil Rehabil. 1997;19(5):194-7.
7. Azevedo DC, Pires FO, Carneiro RL. A pubalgia no jogador de futebol. Rev Bras Med Esporte.1999;20(5):233-8.

8. Magno E Silva MP, Morato MP, Bilzon JU, Duarte E. Sports injuries in Brazilian blind footballers. Int J Sports Med. 2013;34(3):239-43.

9. Clover J. Injuries to tissues. In: Clover J. Sports Medicine Essentials: core concepts in athletic and fitness instruction. Clifton:Delmar Cengage Learning, 2007. p.303-45.

10. Campos LFCC, Borin JP, Santos LGTF, Souza TMFde, Paranhos VMS, Tanhoffer RA, et al. Isokinetic evaluation of Brazilian 5-a-side team. Rev Bras Med Esporte. 2015;21(3):220-3.

11. Willick SE, Webborn N, Emery C, Blauwet CA, Pit-Grosheide P, Stomphorst J, et al. The epidemiology of injuries at the London 2012 Paralympic Games. Br J Sports Med. 2013;47(7):426-32.

12. Webborn N, Cushman D, Blauwet CA, Emery C, Derman W, Schwellnus, M, et al. The Epidemiology of Injuries in Football at the London 2012 Paralympic Games. PMR. 2016;8(6):545-52. 
13. Thomas JR, Nelson JK, Silverman JS. Métodos de pesquisa em atividade física. 6. ed. - Dados eletrônicos. - Porto Alegre: Artmed, 2012.

14. Confederação Brasileira de Desportos para Deficientes Visuais - CBDV. [Internet]. [acesso em 2021 mar 5]. Disponivel em: http://cbdv.org.br/fut5.

15. Magno ESilva, MP. Protocolo de lesão esportiva no esporte paralímpico (PLEEP): proposta para a coleta de dados [Tese]. 2013.171 p. Campinas: Universidade Estadual de Campinas, Faculdade de Educação Física, Campinas, SP. [acesso em 2021 mar 5]; Disponível em: <http://www.repositorio.unicamp.br/handle/REPOSIP/275484>.

16. Bahr R, Clarsen B, Derman W, Dvorak J, Emery CA, Finch CF, et al. International Olympic Committee consensus statement: Methods for recording and reporting of epidemiological data on injury and illness in sport 2020 (including STROBE Extension for Sport Injury and Illness Surveillance (STROBE-SIIS)). Br J Sports Med. 2020;54:372-89.

17. Beaglehole R, Bonita R, Kjellström T. Epidemiologia básica [tradução e revisão científica Juraci A. Cesar]. 2nd. São Paulo: Santos, 2010

18. Knowles SB, Marshall SW, Guskiewicz KM. Issues in estimating risks and rates in sports injury research. J Athl Train. 2006;41(2):207-15.

19. Junge A, Engebretsen L, Alonso JM, Renström P, Mountjoy M, Aubry M, et al. Injury surveillance in multi-sport events: The International Olympic Committee approach. Br J Sports Med. 2008;42(6):413-21.

20. Van Mechelen W, Hlobil H, Kemper HCG. Incidence, severity, aetiology and prevention of sports injuries. Sport Med. 1992;14(2):82-99.
21. Van Mechelen W. The severity of sports injuries. Sport Med.1997;24(3):176-80.

22. Fuller CW, Ekstrand J, Junge A, Andersen TE, Bahr R, Dvorak J, et al. Consensus statement on injury definitions and data collection procedures in studies of football (soccer) injuries. Clin J Sport Med. 2006;16(2):97-106

23. Finocchietti S, Gori M, Oliveira AS. Kinematic Profile of Visually Impaired Football Players During Specific Sports Actions. Scientific reports. 2019;9: 1-8.

24. Peterson L, Renstrom P. Lesões do Esporte. Baruerí: Manole, 2002.

25. Cunha GDS, Ribeiro JL, De Oliveira AR. Sobretreinamento: Teorias, diagnóstico e marcadores. Rev Bras Med Esporte. 2016;12(5):297-302.

26. Gamonales JM, Muñoz-Jiménez J, León-Guzmán K, Ibáñez SJ. 5-A-side football for individuals with visual impairments: A review of the literature. Eur J Adapt Phys Act. 2019;11(1):1-19.

27. Silva MPM, Duarte E, Silva AAC, Silva HGPV, Vital R. Aspectos das lesões esportivas em atletas com deficiência visual. Rev Bras Med Esporte. 2011;17(5):319-23.

28. Campos LFCC, Silva AAC, Santos LGTF, Costa LT, Montagner PC, Borin JP, et al. Effects of training in physical fitness and body composition of the brazilian 5-a-side football team. Rev Andaluza Med del Deport. 2013;6(3):91-5.

29. Zare A, McMullen KA, McCune CG. Design of an accessible and portable system for soccer players with visual impairments. Conf Hum Factors Comput Syst. 2014;1237-42. 